\title{
Prevalence and risk factors of retinopathy of prematurity in Iran: a systematic review and meta-analysis
}

\author{
Milad Azami', Zahra Jaafari ${ }^{2}$, Shoboo Rahmati ${ }^{2}$, Afsar Dastjani Farahani ${ }^{3}$ and Gholamreza Badfar ${ }^{4^{*}}$
}

\begin{abstract}
Background: Retinopathy of prematurity (ROP) refers to the developmental disorder of the retina in premature infants and is one of the most serious and most dangerous complications in premature infants. The prevalence of ROP in Iran is different in various parts of Iran and its prevalence is reported to be $1-70 \%$ in different regions. This study aims to determine the prevalence and risk factors of ROP in Iran.

Methods: This review article was conducted based on the preferred reporting items for systematic review and meta-analysis (PRISMA) protocols. To find literature about ROP in Iran, a comprehensive search was done using MeSH keywords in several online databases such as PubMed, Ovid, Science Direct, EMBASE, Web of Science, CINAHL, EBSCO, Magiran, Iranmedex, SID, Medlib, IranDoc, as well as the Google Scholar search engine until May 2017. Comprehensive Meta-analysis Software (CMA) Version 2 was used for data analysis.
\end{abstract}

Results: According to 42 studies including 18,000 premature infants, the prevalence of ROP was reported to be 23. 5\% (95\% Cl: 20.4-26.8) in Iran. The prevalence of ROP stages 1, 2, 3, 4 and 5 was 7.9\% (95\% Cl: 5.3-11.5), 9.7\% (95\% Cl: 6.1-15.3), 2.8\% (95\% Cl: 1.6-4.9), 2.9\% (95\% Cl: 1.9-4.5) and 3.6\% (95\% Cl: 2.4-5.2), respectively. The prevalence of ROP in Iranian girls and boys premature infants was 18.3\% (95\% Cl: 12.8-25.4) and 18.9\% (95\% Cl: 11.9-28.5), respectively. The lowest prevalence of ROP was in the West of Iran (12.3\% [95\% Cl: 7.6-19.1]), while the highest prevalence was associated with the Center of Iran (24.9\% [95\% Cl: 21.8-28.4]). The prevalence of ROP is increasing according to the year of study, and this relationship is not significant $(p=0.181)$. The significant risk factors for ROP were small gestational age $(p<0.001)$, low birth weight $(p<0.001)$, septicemia $(p=0.021)$, respiratory distress syndrome $(p=0.036)$, intraventricular hemorrhage $(p=0.005)$, continuous positive pressure ventilation $(p=0.023)$, saturation above $50 \%(p=0.023)$, apnea $(p=0.002)$, frequency and duration of blood transfusion, oxygen therapy and phototherapy $(p<0.05)$, whereas pre-eclampsia decreased the prevalence of ROP $(p=0.014)$.

Conclusion: Considering the high prevalence of ROP in Iran, screening and close supervision by experienced ophthalmologists to diagnose and treat the common complications of pre-maturity and prevent visual impairment or blindness is necessary.

Keywords: Meta-analysis, Retinopathy of prematurity, Iran, Prevalence, Risk factor

\footnotetext{
* Correspondence: Gh_badfar@yahoo.com

${ }^{4}$ Department of Pediatrics, Behbahan Faculty of Medical Sciences, Behbahan, Iran

Full list of author information is available at the end of the article
} 


\section{Background}

Retinopathy of prematurity (ROP) refers to the developmental disorder of the retina in premature infants and is one of the most serious and most dangerous complications in premature infants.

Embryonic retinal arteries start to grow in the third month of pregnancy and their development ends at birth. Therefore, the stages of evolution of the eye are defective in premature infants, and the growth of the vessels is either stopped or unusual, and ultimately, the vessels become very fragile, which can lead to visual impairment in severe cases [1].

Despite considerable progress made in the treatment of ROP, it is still a common cause of reduced vision in children in developed countries, and its prevalence is increasing [2-4]. This is a preventable disease and responds to treatments appropriately if diagnosed at early stages, but in case of delayed diagnosis and treatment, it may lead to blindness [5].

The first incidences of ROP were reported in the 1940s and 1950s, mainly as a result of the use of supplemental oxygen without supervision (first epidemic). Although the survival of premature infants improved in the following decades, and despite improved monitoring methods for oxygen supplements, ROP emerged with an increasing incidence (second epidemic) [6]. Over the past decade, the increasing incidence of ROP blindness has been recorded in low-income countries. Studies show that ROP is the leading cause of blindness in China, Southeast Asia, South America, Latin America, and Eastern Europe, especially in urban centers of newly industrialized countries, and this is referred to as the "third epidemic" [7].

ROP is a multifactorial disease and the most important risk factors are preterm delivery, especially before the 32nd week of gestation and birth weight less than $1500 \mathrm{~g}$. Apnea, intraventricular hemorrhage, various maternal factors (diabetes, preeclampsia, mother's smoking), respiratory disorders, infection, vitamin E deficiency, heart disease, increased blood carbon dioxide, increased oxygen $\left(\mathrm{O}_{2}\right)$ consumption, decreased $\mathrm{PH}$, decreased blood $\mathrm{O} 2$, bradycardia, transfusion, amount of received oxygen and duration of ventilation are other risk factors for ROP [8-10].

The prevalence of ROP in different regions of Iran is different and its prevalence is reported to be $1-70 \%$ in different regions [11-14]. Considering the abovementioned issues and the importance of the subject, as well as the diversity of reports in Iranian studies, it is necessary to carry out more extensive and precise studies. Meta-analysis is a method that collects and analyzes multiple research data with a common purpose to provide a reliable estimate of the impact of some interventions or observations in medicine $[15,16]$. Obviously, the sample size in meta-analysis becomes larger by collecting data from several studies and therefore the range of changes and probabilities will be reduced; therefore, the significance of statistical results increases $[16,17]$. This study aims to determine the incidence and risk factors for ROP in Iran.

\section{Methods \\ Study protocol}

This review article was conducted based on the preferred reporting items for systematic review and meta-analysis (PRISMA) protocols [16]. The study was conducted in five stages: design and search strategy, a collection of articles and their systematic review, evaluation of inclusion and exclusion criteria, qualitative evaluation and statistical analysis of data. To avoid bias in the study, each of the above steps was carried out by two researchers independently. In case of differences in the results obtained by the two researchers, a third researcher intervened to reach an agreement.

\section{Search strategy}

To find literature about ROP in Iran, a comprehensive search was done using the terms (Retinopathy of Prematurity $[\mathrm{MeSH}]$ ) AND ("Incidence" [MeSH] OR "Epidemiology" $[\mathrm{MeSH}]$ ), OR ("Prevalence" [MeSH]) AND ("Iran" $[\mathrm{MeSH}])$ in 7 international databases including PubMed, Ovid, Science Direct, EMBASE, Web of Science, CINAHL, EBSCO, and 5 national databases including Magiran, Iranmedex, SID, Medlib, IranDoc, as well as Google Scholar search engine until May 2017. References to all relevant articles were reviewed. Due to the inability of Iranian databases to search using Boolean operators (AND, OR and NOT), searches on these databases were only performed using the keywords.

\section{Inclusion and exclusion criteria}

Articles with the following characteristics were chosen for meta-analysis: 1 . Original research papers published either in Persian or English; 2. Medical dissertations; 3. Review of the prevalence or risk factors for ROP. The exclusion criteria were: 1 . Non-random sample for estimating the prevalence; 2. Being irrelevant to the topic; 3. Congress papers; 4 . Sample size other than premature infants; 5. Non-Iranian studies; 6. Review articles, case reports, editorials; 7. Duplicate studies and 8. Lowquality studies.

\section{ROP detection criteria}

ROP was diagnosed by an expert through examination of retinas of infants using indirect ophthalmoscope.

\section{Selection of studies}

First, all related articles (articles with affiliations containing Iranian authors) were collected and a list of titles was prepared at the end of the search and removal of duplicates. After blinding the specifications of the articles by on 
researcher (Milad Azami), including the name of the journal and the name of the author, the full text of the articles was presented to the researchers. Each article was studied by two researchers independently (Gholamreza Badfar, Afsar Dastjani Farahani). If the article was rejected, the reason for this rejection was mentioned. In case of disagreement between the two authors, the article was judged by the team of researchers.

\section{Quality of studies}

Using the standard modified Newcastle Ottawa Scale (NOS) checklist [18], which included 8 sections. Thus, the minimum and maximum score available on this checklist were 0 and 8, respectively. Accordingly, the studies were divided into three categories: 1 . low quality with a score less than $5 ; 2$. moderate quality with a score of $5-6$; and 3 . high quality with a score of $7-8$. Finally, the moderate to high quality studies were selected for the meta-analysis stage.

\section{Data extraction}

The raw data of the prepared articles were extracted using a premade checklist. The checklist includes the name of the authors, published year the year of study, the location of the study, the study design, quality score, sample size, the prevalence of ROP, the ROP detection criteria, the prevalence of ROP based on gender (ROP) and ROP risk factors.

\section{Statistical analysis}

In each study, the prevalence of ROP was considered as the probability of binomial distribution. To evaluate the heterogeneity of the studies, Cochran's Q test and $\mathrm{I}^{2}$ index were used [19]. There are three categories for the $\mathrm{I}^{2}$ index: heterogeneity lower than $25 \%$, heterogeneity between $25 \%$ and $75 \%$ and heterogeneity more than $75 \%$. Considering the heterogeneity of the studies, a random effects model was used to combine ROP prevalence. For ROP risk factors, the fixed effects model and the random effects model were used, respectively in the case of low heterogeneity and high heterogeneity in the metaanalysis $[20,21]$. Sensitivity analysis was performed to identify the influence of a single study on the combined result incidence or any risk factors (with $\geq$ 7 studies). In order to identify the cause of heterogeneity of ROP prevalence, sub-groups analysis of ROP were carried out based on geographical region, province and quality of studies, while the metaregression model (method of moments) was carried out based on the year of studies [22]. Egger and Begg's tests were used to identify publications bias. Data analysis was performed using Comprehensive Meta-Analysis Software Version 2 and the significance level in the tests was considered to be lower than 0.05 .

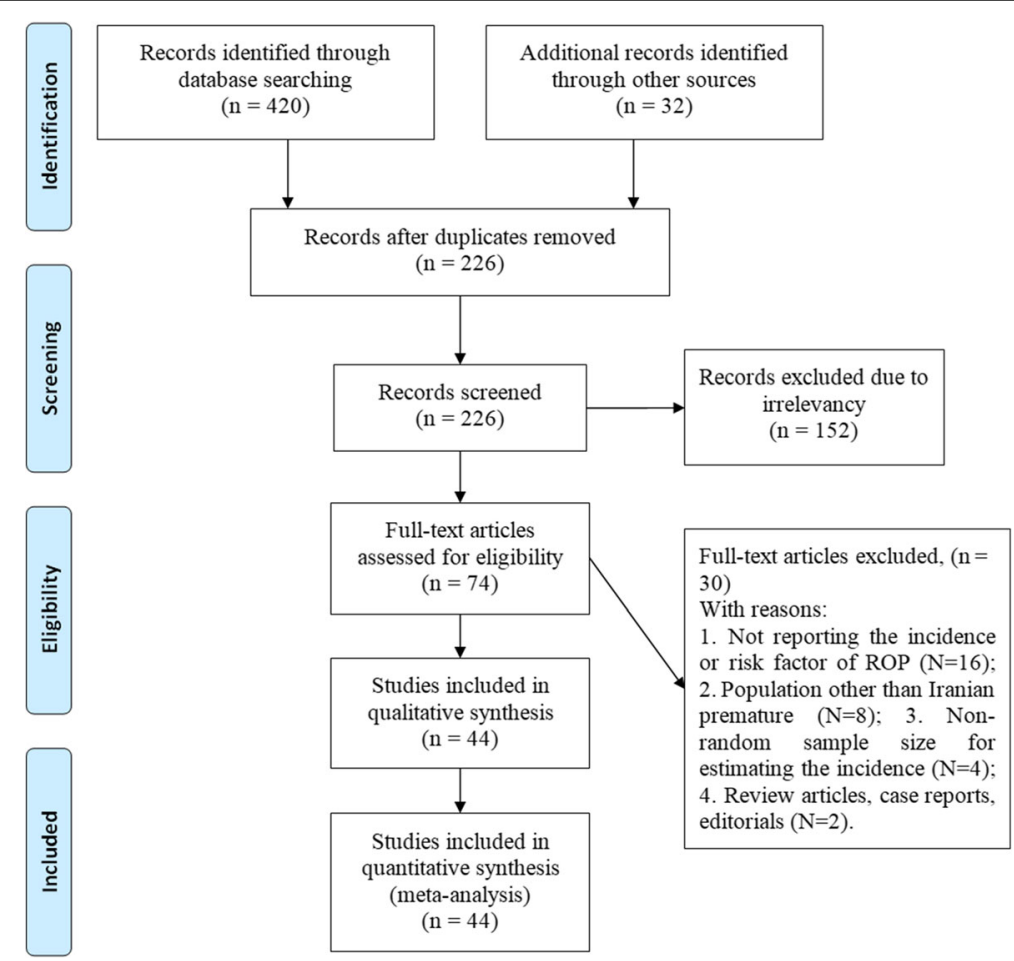

Fig. 1 PRISMA flowchart for the selection of studies 
Table 1 Summary of demographic characteristics in studies into a meta-analysis

\begin{tabular}{|c|c|c|c|c|c|c|c|c|c|c|}
\hline \multirow[t]{2}{*}{ Ref. } & \multirow{2}{*}{$\begin{array}{l}\text { First author, Published } \\
\text { Year }\end{array}$} & \multirow{2}{*}{$\begin{array}{l}\text { Year } \\
\text { of } \\
\text { study }\end{array}$} & \multirow[t]{2}{*}{$\mathrm{GA}^{\mathrm{a}}$ (week) } & \multirow[t]{2}{*}{$\mathrm{BW}^{\mathrm{b}}(\mathrm{gr})$} & \multirow[t]{2}{*}{ Place } & \multicolumn{3}{|c|}{ Sample size } & \multirow[t]{2}{*}{ Prevalence (\%) } & \multirow[t]{2}{*}{ Quality } \\
\hline & & & & & & $\overline{\text { All }}$ & Non-ROPC & $\overline{R O P}$ & & \\
\hline [11] & Naderian Gh, 2011 & 2009 & $<34$ & And $\leq 1800$ & Isfahan & 100 & 71 & 29 & 29 & Moderate \\
\hline [11] & Naderian Gh(1), 2011 & 2009 & $<34$ & And $\leq 1800$ & Isfahan & 100 & 58 & 42 & 42 & Moderate \\
\hline $\begin{array}{l}{[12,} \\
13]\end{array}$ & $\begin{array}{l}\text { Mostafa Gharebagh M, } \\
2012\end{array}$ & 2008 & $<34$ & - & Tabriz & 71 & 41 & 30 & & High \\
\hline [14] & Nakhshab M, 2016 & 2014 & $<30$ or $<34^{d}$ & - & Sari & 146 & 122 & 24 & 16.44 & High \\
\hline [52] & Naderian G, 2009 & 2002 & $25-34$ & And 600-1800 & Isfahan & 796 & 662 & 134 & 16.8 & Moderate \\
\hline [53] & Hosseini H, 2009 & 2006 & $<34$ & - & Shiraz & 1024 & 1004 & 20 & 1.95 & High \\
\hline [54] & Karkhaneh R, 2005 & 2000 & $\leq 37$ & And $\leq 2500$ & Tehran & 185 & 162 & 23 & 12.4 & High \\
\hline [55] & Naderian G, 2010 & 2003 & - & - & Isfahan & 604 & 498 & 106 & 17.5 & High \\
\hline$[56]$ & Mansouri M, 2007 & 2004 & $\leq 32$ & And $\leq 1500$ & Tehran & 147 & 103 & 44 & 29.9 & High \\
\hline [57] & Nakshab M, 2003 & 2001 & - & $\leq 2500$ & Sari & 68 & 60 & 8 & 11.7 & High \\
\hline [58] & Daraie G, 2016 & 2008 & $<37$ & Or $<2000$ & Semnan & 270 & 267 & 3 & 1.1 & Moderate \\
\hline [59] & Fayazi A,2009 & 2005 & $<32$ & $\begin{array}{l}\text { Or }<1500 \text { or } 1500- \\
2500^{*}\end{array}$ & Tabriz & 399 & 370 & 29 & 7.26 & Moderate \\
\hline$[60]$ & Sadeghi K, 2008 & 2006 & $<36$ & And $<2000$ & Tabriz & 150 & 124 & 26 & 17.3 & Moderate \\
\hline [61] & Ebrahimiadib N, 2016 & 2011 & $<37$ & Or $<3000$ & Tehran & 1896 & 1326 & 570 & 30.06 & Moderate \\
\hline$[62]$ & Ghaseminejad A, 2011 & 2006 & $\leq 36$ & And $\leq 2500$ & Kerman & 83 & 59 & 24 & 29 & High \\
\hline [63] & Khatami F, 2008 & 2000 & $<34$ & Or $<2000$ & Mashhad & 50 & 36 & 14 & 28 & Moderate \\
\hline [64] & Sabzehei MK, 2013 & 2007 & - & $<1500$ & Tehran & 414 & 343 & 71 & 17.14 & Moderate \\
\hline$[65]$ & Saeidi R, 2009 & 2005 & $\leq 32$ & Or $<1500$ & Mashhad & 47 & 43 & 4 & 8.5 & Moderate \\
\hline [66] & Azin Far B, 2005 & 2001 & $<29$ & And $<1500$ & Babol & 100 & 56 & 44 & 44 & High \\
\hline [67] & Karkhanehyousefi N, 2009 & 2009 & - & - & Babol & 100 & 61 & 39 & 39 & Moderate \\
\hline [68] & Ebrahimzadeh A, 2009 & 2003 & - & - & Tehran & 1343 & 874 & 469 & 34.9 & High \\
\hline [69] & Mirzaee SA, 2010 & 2008 & - & $<2000$ & Tehran & 74 & 50 & 24 & 324 & Moderate \\
\hline [70] & Mousavi Z, 2009 & 2001 & $24-36$ & And 600-2900 & Tehran & 797 & 540 & 257 & 32.24 & Moderate \\
\hline$[71]$ & Fouladinejad M, 2009 & 2004 & $\leq 34$ & - & Gorgan & 89 & 84 & 5 & 5.6 & High \\
\hline [72] & Mousavi S, 2008 & 2001 & $24-36$ & And $600-2800$ & Tehran & 693 & 474 & 219 & 31.6 & Moderate \\
\hline [73] & Sadeghzadeh M, 2016 & 2001 & - & $450-3000$ & Zanjan & 78 & 77 & 1 & 1.2 & Moderate \\
\hline [74] & Bayat-Mokhtari M, 2010 & 2006 & - & $\begin{array}{l}<1500 \text { Or } \\
1500-2000^{*}\end{array}$ & Shiraz & 199 & 115 & 84 & 42 & High \\
\hline [75] & Karkhaneh R, 2001 & 1997 & $<37$ & Or $<2500$ & Tehran & 150 & 141 & 9 & 6 & High \\
\hline [76] & Babaei H, 2012 & 2009 & - & $\leq 1500$ & Kermanshah & 84 & 73 & 11 & 13.1 & Moderate \\
\hline$[77]$ & Abrishami M, 2013 & 2006 & $<32$ & - & Mashhad & 122 & 90 & 32 & 26.2 & High \\
\hline$[78]$ & Riazi-Esfahani M, 2008 & 2002 & $\leq 37$ & And $\leq 2500$ & Tehran & 165 & 125 & 40 & 24.24 & Moderate \\
\hline$[79]$ & Alizadeh Y, 2015 & 2005 & $\leq 36$ & And $\leq 2500$ & Rasht & 310 & 246 & 64 & 20.6 & High \\
\hline$[80]$ & Mousavi SZ, 2010 & 2003 & - & - & Tehran & 605 & 415 & 190 & 31.4 & Moderate \\
\hline$[81]$ & Mousavi Z, 2010 & 2003 & - & - & Tehran & 1053 & 673 & 380 & 36.1 & High \\
\hline$[82]$ & Feghhi M, 2012 & 2006 & $<32$ & And $\leq 2000$ & Ahvaz & 576 & 393 & 183 & 32 & High \\
\hline [83] & Afarid M, 2012 & 2006 & $\leq 32$ & And $\leq 2000$ & Shiraz & 787 & 494 & 293 & 37.2 & Moderate \\
\hline$[84]$ & Ahmadpourkacho M, 2014 & 2009 & $<28$ & $\begin{array}{l}\text { And }<1500 \text { or } \\
1500-2000^{*}\end{array}$ & Babol & 256 & 76 & 180 & 70.31 & High \\
\hline$[85]$ & AhmadpourKacho M, 2014 & 2007 & $<34$ & And $<2000$ & Babol & 155 & 85 & 70 & 45.2 & Moderate \\
\hline$[86]$ & Rasoulinejad SA, 2016 & 2007 & $<36$ & And $<2500$ & Babol & 680 & 374 & 306 & 45 & High \\
\hline$[87]$ & Karkhaneh R, 2008 & 2003 & $<37$ & - & Tehran & 953 & 624 & 329 & 34.5 & High \\
\hline
\end{tabular}


Table 1 Summary of demographic characteristics in studies into a meta-analysis (Continued)

\begin{tabular}{|c|c|c|c|c|c|c|c|c|c|c|}
\hline \multirow[t]{2}{*}{ Ref. } & \multirow{2}{*}{$\begin{array}{l}\text { First author, Published } \\
\text { Year }\end{array}$} & \multirow{2}{*}{$\begin{array}{l}\text { Year } \\
\text { of } \\
\text { study }\end{array}$} & \multirow[t]{2}{*}{$\mathrm{GA}^{\mathrm{a}}$ (week) } & \multirow[t]{2}{*}{$\mathrm{BW}^{\mathrm{b}}(\mathrm{gr})$} & \multirow[t]{2}{*}{ Place } & \multicolumn{3}{|c|}{ Sample size } & \multirow[t]{2}{*}{ Prevalence (\%) } & \multirow[t]{2}{*}{ Quality } \\
\hline & & & & & & $\overline{\text { All }}$ & Non-ROPC & $\overline{R O P}$ & & \\
\hline [88] & Khalesi N, 2015 & 2013 & - & - & Tehran & 120 & 60 & 60 & & Moderate \\
\hline [89] & Ebrahim M, 2010 & 2004 & $<37$ & - & Babol & 173 & 140 & 33 & 19.1 & High \\
\hline$[90]$ & Roohipoor R, 2016 & 2012 & $\leq 37$ & And $\leq 3000$ & Tehran & 1932 & 1362 & 570 & 3 & High \\
\hline [91] & Mansouri M, 2016 & 2013 & $<34$ & Or $<2000$ & Sanandaj & 47 & 42 & 5 & 10.6 & High \\
\hline
\end{tabular}

${ }^{\mathrm{a}}$ Gestational age; ${ }^{\mathrm{b}}$ Birth weight; ${ }^{\mathrm{c}}$ Retinopathy of prematurity; ${ }^{\mathrm{d}}$ With unstable condition

\section{Results}

\section{Search results and characteristics}

In the initial search, 452 studies were found to be related to the topic. Two independent researchers reviewed the title and the abstract. If the title or abstract was likely to be related to the topic, the full text was reviewed. After reviewing the full text of 74 relevant articles, 30 articles were omitted due to lacking the necessary criteria and finally 44 qualified studies entered the qualitative assessment stage (Fig. 1). Table 1 shows the characteristics of each study.

\section{Prevalence}

Reviewing 42 studies with a total sample size of 18,000 premature infants, the prevalence of ROP in Iran was estimated to be $23.5 \%$ (95\% CI: 20.4-26.8). The lowest and highest prevalence was related to the studies in Semnan (2008) (1.1\%) (58) and in Babol (2009) (70.3\%) (84), respectively (Fig. 2).

\section{Sensitivity analysis and cumulative analysis for ROP}

The sensitivity analysis of the prevalence or risk factors of ROP and its 95\% confidence interval (CI) was estimated simultaneously regardless of one study and the results showed that the incidence or risk factors of ROP were not significantly changed before and after the deletion of each study. (Fig. 3a). Cumulative analysis for incidence of ROP based on the year of publication is shown in Fig. $3 \mathrm{~b}$.

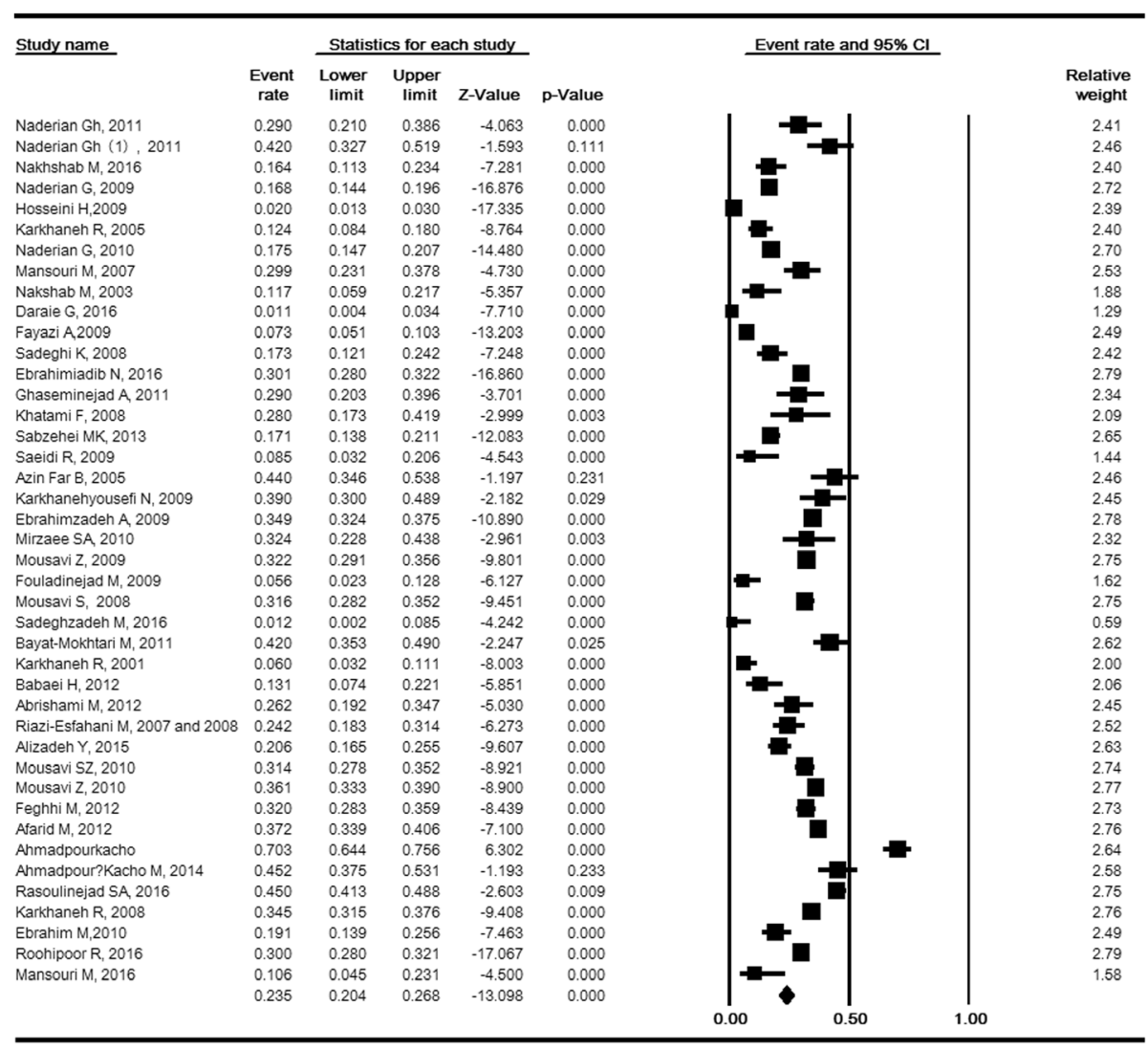

Meta Analysis

Fig. 2 The prevalence of retinopathy of prematurity in Iran. Random effects model 
a

Study name

Naderian Gh, 2011

Naderian $\mathrm{Gn}(1), 2011$

Nakhshab M, 2016

Naderian G, 2009
Hosseini H,2009

Hosseini $H, 2009$
Karkhaneh R, 2005

Naderian G, 2010

Mansouri M, 2007

Nakshab M, 2003

Fayazi A,2009

Sadeghi K, 2008

Ebrahimiadib N, 2016

Khatami F, 2008

Sabzehei MK, 2013

Saeidi $R, 2009$

Azin Far B, 2005

Ebrahimzadeh A, 2009

Mirzaee SA, 2010

Mousavi Z, 2009

Fouladinejad M, 2009

Mousavi S, 2008

Sadeghzadeh M, 2016
Bayat-Mokhtari M, 2011

Bayat-Mokhtari M, 2011
Karkhanen R, 2001

Babaei H, 2012

Abrishami M, 2012

Riazi-Esfahani M, 2007 and 2008

Alizadeh $Y, 2015$

Mousavi SZ, 2010

Mousavi Z, 2010

Feghhi M, 2012

Ahmadpour-kacho M (1) 2014

Ahmadpour-kacho M, 2014

Rasoulinejad SA, 20

Karkhaneh R, 2000

Ebrahim M,2010
Roohipoor R. 2016

Mansouri M, 2016
Statistics with study removed

Lower
limit limit

Z-Value p-Value

$\begin{array}{lllll}0.233 & 0.203 & 0.267 & -12.979 & 0.000 \\ 0.231 & 0.201 & 0.264 & -13.160 & 0.000\end{array}$

$\begin{array}{lllll}0.237 & 0.206 & 0.271 & -12.853 & 0.000\end{array}$

$\begin{array}{lllll}0.238 & 0.207 & 0.271 & -12.992 & 0.000 \\ 0.250 & 0.221 & 0.282 & -13.252 & 0.000\end{array}$

$\begin{array}{lllll}0.239 & 0.208 & 0.272 & -12.833 & 0.000\end{array}$

$\begin{array}{lllll}0.237 & 0.206 & 0.271 & -12.923 & 0.000\end{array}$

$\begin{array}{lllll}0.233 & 0.202 & 0.267 & -12.970 & 0.000\end{array}$

$\begin{array}{lllll}0.238 & 0.207 & 0.272 & -12.835 & 0.000\end{array}$

$\begin{array}{lllll}0.243 & 0.212 & 0.277 & -12.744 & 0.000 \\ 0.242 & 0.212 & 0.275 & -12.942 & 0.000\end{array}$

$\begin{array}{lllll}0.242 & 0.212 & 0.275 & -12.942 & 0.000 \\ 0.237 & 0.206 & 0.270 & -12.859 & 0.000\end{array}$

$\begin{array}{lllll}0.237 & 0.206 & 0.270 & -12.859 & 0.000 \\ 0.231 & 0.199 & 0.267 & -12.414 & 0.000\end{array}$

$\begin{array}{llllll}0.233 & 0.203 & 0.267 & -12.986 & 0.000\end{array}$

$\begin{array}{lllll}0.224 & 0.203 & 0.267 & -12.995 & 0.000 \\ 0.237 & 0.206 & 0.271 & -12890 & 0.000\end{array}$

$\begin{array}{lllll}0.238 & 0.207 & 0.279 & -12.890 & 0.000\end{array}$

$\begin{array}{lllll}0.231 & 0.200 & 0.264 & -13.194 & 0.000\end{array}$

$\begin{array}{llllll}0.231 & 0.201 & 0.265 & -13111 & 0.000\end{array}$

$\begin{array}{llllll}0.231 & 0.199 & 0265 & -12673 & 0.000\end{array}$

$\begin{array}{lllll}0.233 & 0.202 & 0.266 & -13.030 & 0.000\end{array}$

$\begin{array}{lllll}0.232 & 0.201 & 0.266 & -12.774 & 0.000\end{array}$

$\begin{array}{lllll}0.240 & 0.209 & 0.274 & -12.783 & 0.000\end{array}$

$\begin{array}{lllll}0.232 & 0.201 & 0.266 & -12.799 & 0.000\end{array}$

$\begin{array}{lllll}0.238 & 0.208 & 0.272 & -12.905 & 0.000\end{array}$

$\begin{array}{llllll}2.241 & 0.210 & 0.275 & -12.767 & 0.000\end{array}$

$\begin{array}{lllll}0.238 & 0.207 & 0.271 & -12.836 & 0.000\end{array}$

$\begin{array}{lllll}0.234 & 0.203 & 0.268 & -12.939 & 0.000 \\ 0.234 & 0.204 & 0.268 & -12906 & 0.000\end{array}$

$\begin{array}{lllll}0.236 & 0.205 & 0.269 & -12.866 & 0.000\end{array}$

$\begin{array}{lllll}0.232 & 0.201 & 0.266 & -12.827 & 0.000\end{array}$

$\begin{array}{lllll}0.231 & 0.200 & 0.265 & -12.798 & 0.000\end{array}$

$\begin{array}{lllll}0.231 & 0.200 & 0.266 & -12.845 & 0.000 \\ 0.265 & -12.908 & 0.000\end{array}$

$\begin{array}{lllll}0.227 & 0.199 & 0.258 & -14.384 & 0.000 \\ 0.230 & 0.200 & 0.263 & -13.227 & 0.000\end{array}$

$\begin{array}{lllll}0.230 & 0.200 & 0.263 & -13.227 & 0.000 \\ 0.263 & -13.316 & 0.000\end{array}$

$\begin{array}{lllll}.231 & 0.200 & 0.265 & -12.773 & 0.000\end{array}$

$\begin{array}{lllll}0.236 & 0.205 & 0.270 & -12.869 & 0.000 \\ 0.231 & 0.199 & 0.267 & -12404 & 0.000\end{array}$

$\begin{array}{lllll}0.231 & 0.199 & 0.267 & -12.404 & 0.000 \\ 0.238 & 0.207 & 0.271 & -12855 & 0.000\end{array}$

$\begin{array}{lllll}0.235 & 0.204 & 0.271 & -12.855 & 0.000\end{array}$

Event rate $(95 \% \mathrm{Cl})$ with study removed

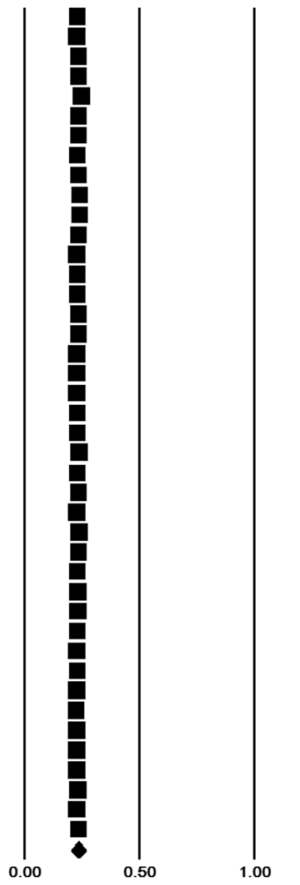

Meta Analysis

b

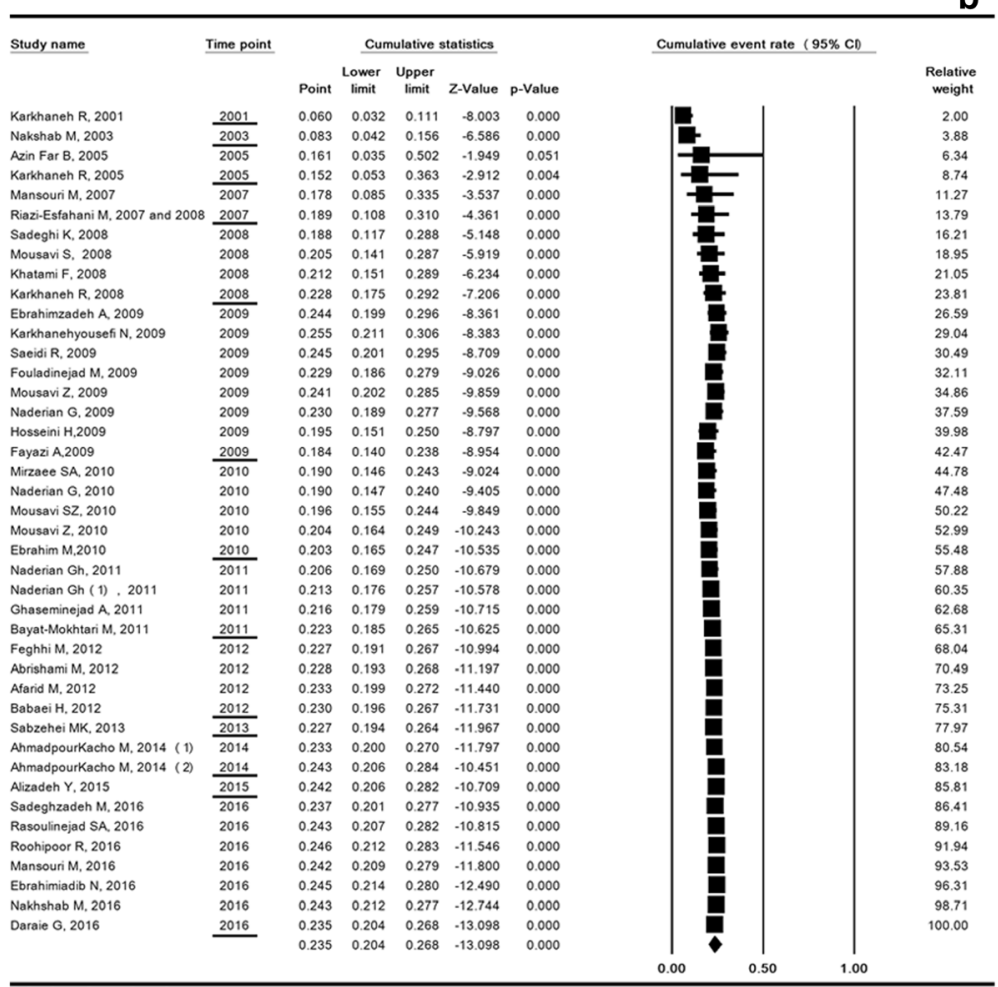

Meta Analysis

Fig. 3 Sensitivity analysis (a) and cumulative analysis based on the year of publication (b) for prevalence of retinopathy of prematurity in Iran. Random effects model 


\section{Subgroup analysis of ROP prevalence based on geographic region}

In the reviewed studies, 2, 4, 12, 4, and 20 studies were related to the West, East, North, South, and Center of Iran, respectively. The prevalence of ROP in the five regions of Iran is shown in Table 2 and the lowest incidence of ROP was in west of Iran (12.3\% [95\% CI: 7.619.1]), while the highest prevalence was related to the center of Iran (24.9\% [95\% CI: 21.8-28.4]) (Table 2).

Subgroup analysis of ROP prevalence based on province Table 2 and Fig. 4 show the prevalence of ROP based on Iran's provinces. The highest prevalence was in provinces of Mazandaran (34.8\%) and Khuzestan (32\%), and the lowest prevalence was in the provinces of Semnan (1.1\%) and Zanjan (1.2\%).

\section{Subgroup analysis of ROP prevalence based on the quality of studies}

The prevalence of ROP in moderate and high-quality studies was $23.5 \%$ (95\% CI: $16.6-28.0)$ and $23.5 \%$ (95\% CI: 19.1-28.7), respectively, and the difference was not statistically significant $(p=0.995)$ (Table 2$)$.

\section{The prevalence of ROP based on gender}

The prevalence of ROP in girls and boys premature infants was $18.3 \%$ (95\% CI: $12.8-25.4)$ and $18.9 \%$ (95\% CI: 11.9-28.5), respectively. Their difference was not statistically significant $(P=0.501)$ (Table 2$)$.

\section{The prevalence of ROP based on stage}

The prevalence of stages $1,2,3,4$ and 5 were reported in 10, eight, nine, five, and five studies, respectively. Fig. 5 shows the prevalence of ROP at different stages. The

Table 2 The prevalence of ROP based on region, gender, provinces and quality of studies

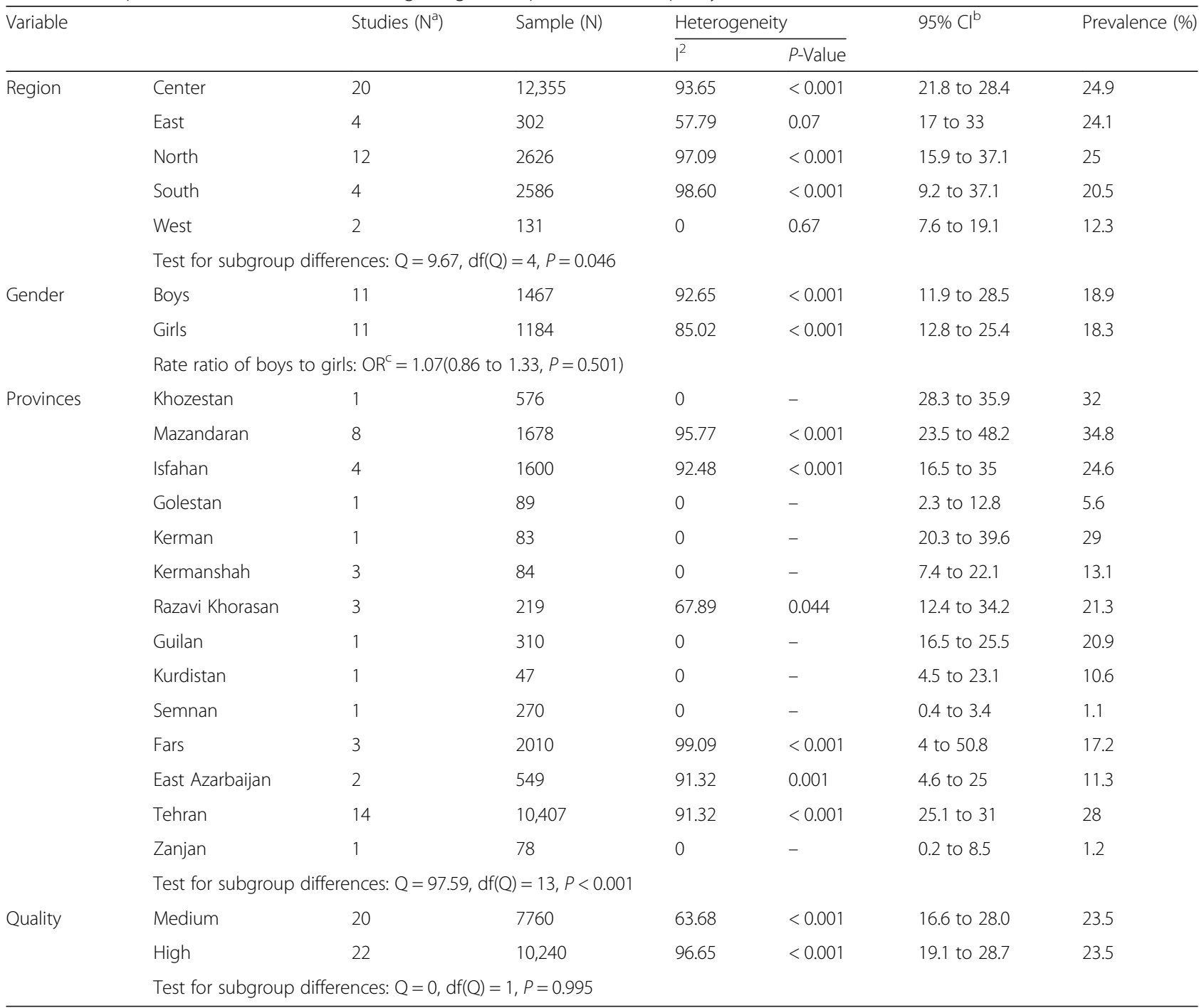




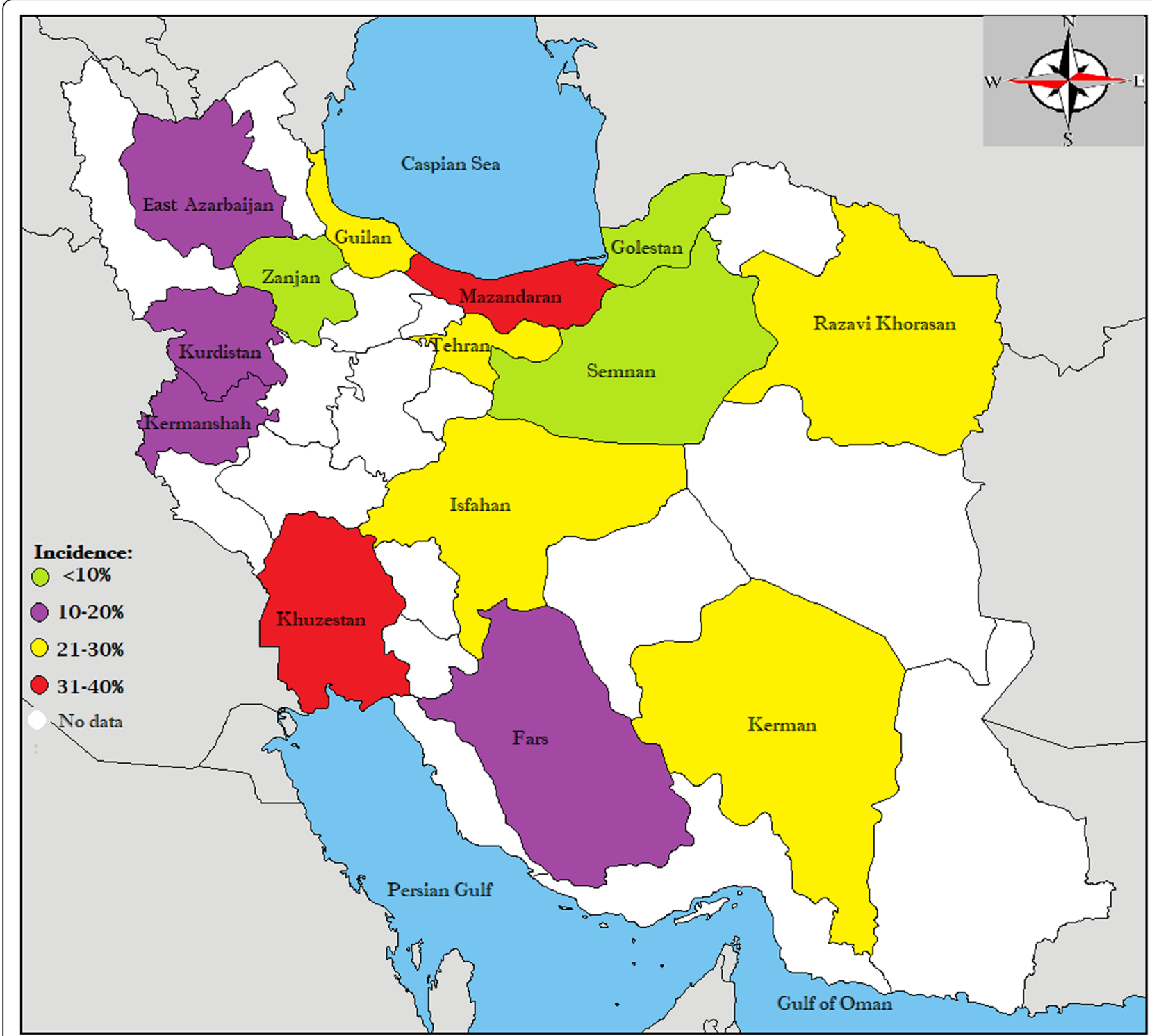

Fig. 4 Geographical distribution of retinopathy of prematurity in Iran

prevalence of stages 1, 2, 3, 4 and 5 was $7.9 \%$ (95\% CI: $5.3-$ 11.5), 9.7\% (95\% CI: 6.1-15.3), 2.8\% (95\% CI: 1.6-4.9), $2.9 \%$ (95\% CI: 1.9-4.5), and 3.6\% (95\% CI: 2.4-5.2), respectively.

\section{Meta-regression}

Meta-regression model in Fig. 6 shows that the incidence of ROP is increasing according to the year of study, and this relationship is not statistically significant (meta-regression coefficient: $0.034,95 \%$ CI -0.016 to $0.085, P=0.181)$.

\section{Publication bias}

The significance level of publication bias in the reviewed studies was 0.003 and 0.002 according to Egger and Begg's tests, respectively, which is shown in Fig. 7.

\section{ROP risk factors}

The meta-analysis results of evaluating the risk factors of ROP are shown in Table 3. ROP risk factors include certain variables such as continuous positive pressure (CPAP) $(P=0.023)$, the prevalence of blood transfusion $\quad(P=0.001)$, septicemia $\quad(P=0.021)$, weight $<1000 \mathrm{~g} \quad(P<0.001)$, weight $<1500 \mathrm{~g}(P<$ $0.0001)$, frequency of phototherapy $(P<0.0001)$, the frequency of oxygen therapy $(P=0.049)$, apnea $(P=$ $00.2)$, intraventricular hemorrhage (IVH) $(P=0.005)$, respiratory distress syndrome (RDS) $(P=0.036)$, gestational age $(\mathrm{GA}) \leq 28$ W(week $)(P<0.001)$, GA $\leq 32 \mathrm{~W}(P<0.001)$, saturation over $50 \%(P<0.001)$, mean GA $(P<0.001)$, mean weight $(P<0.0001)$, oxygen therapy duration $(P<0.001)$ and phototherapy 


\begin{tabular}{|c|c|c|c|c|c|}
\hline \multirow[t]{2}{*}{ Study name } & \multirow[b]{2}{*}{$\begin{array}{c}\text { Event } \\
\text { rate }\end{array}$} & \multicolumn{3}{|c|}{ Statistics for each study } & \multirow[b]{2}{*}{$\mathrm{p}$-Value } \\
\hline & & $\begin{array}{c}\text { Lower } \\
\text { limit }\end{array}$ & $\begin{array}{c}\text { Upper } \\
\text { limit }\end{array}$ & Z-Value & \\
\hline Nakhshab M, 2016 & 0.041 & 0.019 & 0.088 & -7.553 & 0.000 \\
\hline Sabzehei MK, 2013 & 0.005 & 0.001 & 0.019 & -7.502 & 0.000 \\
\hline Azin Far B, 2005 & 0.250 & 0.175 & 0.344 & -4.757 & 0.000 \\
\hline Babaei H, 2012 & 0.060 & 0.025 & 0.135 & -5.985 & 0.000 \\
\hline Abrishami M, 2012 & 0.131 & 0.082 & 0.203 & -7.051 & 0.000 \\
\hline Alizadeh Y, 2015 & 0.100 & 0.071 & 0.139 & -11.606 & 0.000 \\
\hline Feghhi M, 2012 & 0.052 & 0.037 & 0.073 & -15.470 & 0.000 \\
\hline Afarid M, 2012 & 0.125 & 0.103 & 0.149 & -18.065 & 0.000 \\
\hline Rasoulinejad SA, 2016 & 0.076 & 0.059 & 0.099 & -17.264 & 0.000 \\
\hline \multirow[t]{2}{*}{ Mansouri M, 2016} & 0.064 & 0.026 & 0.148 & -5.647 & 0.000 \\
\hline & 0.079 & 0.053 & 0.115 & -11.624 & 0.000 \\
\hline
\end{tabular}

Event rate and $95 \% \mathrm{Cl}$

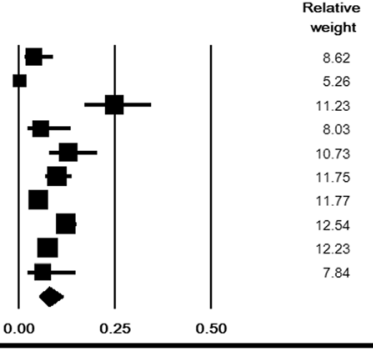

Meta Analysis

b

\begin{tabular}{|c|c|c|c|c|c|}
\hline \multirow[t]{2}{*}{ Study name } & \multirow[b]{2}{*}{$\begin{array}{l}\text { Event } \\
\text { rate }\end{array}$} & \multicolumn{3}{|c|}{ Statistics for each study } & \multirow[b]{2}{*}{ p-Value } \\
\hline & & $\begin{array}{c}\text { Lower } \\
\text { limit }\end{array}$ & $\begin{array}{c}\text { Upper } \\
\text { limit }\end{array}$ & Z-Value & \\
\hline Nakhshab M, 2016 & 0.095 & 0.057 & 0.154 & -7.986 & 0.000 \\
\hline Sabzehei MK, 2013 & 0.014 & 0.006 & 0.032 & -10.244 & 0.000 \\
\hline Babaei H, 2012 & 0.060 & 0.025 & 0.135 & -5.985 & 0.000 \\
\hline Abrishami M, 2012 & 0.057 & 0.027 & 0.115 & -7.186 & 0.000 \\
\hline Alizadeh Y, 2015 & 0.061 & 0.039 & 0.094 & -11.523 & 0.000 \\
\hline Feghhi M, 2012 & 0.189 & 0.159 & 0.223 & -13.679 & 0.000 \\
\hline Afarid M. 2012 & 0.182 & 0.156 & 0.210 & -16.279 & 0.000 \\
\hline \multirow[t]{2}{*}{ Rasoulinejad SA, 2016} & 0.284 & 0.251 & 0.319 & -10.883 & 0.000 \\
\hline & 0.097 & 0.061 & 0.153 & -8.520 & 0.000 \\
\hline
\end{tabular}

Event rate and $95 \% \mathrm{Cl}$

Meta Analysis

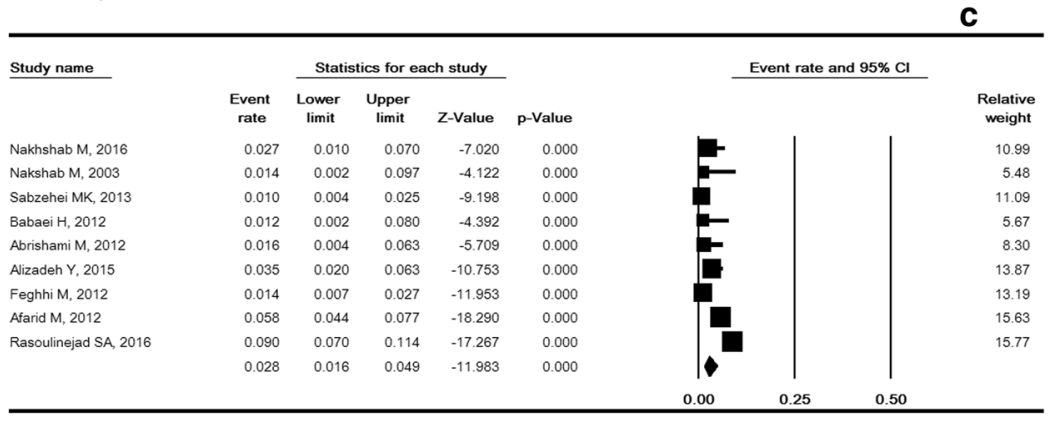

Meta Analysis

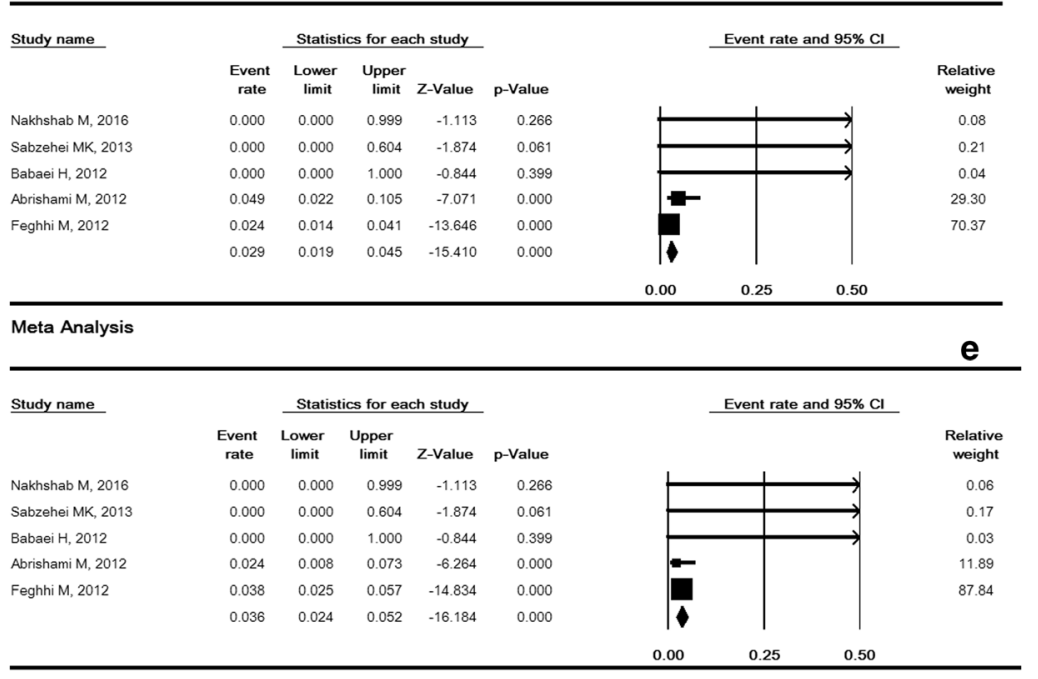

Meta Analysis

Fig. 5 The prevalence of stages I (a), II (b), III (c), IV (d), V (e) retinopathy of prematurity. Random effects model 


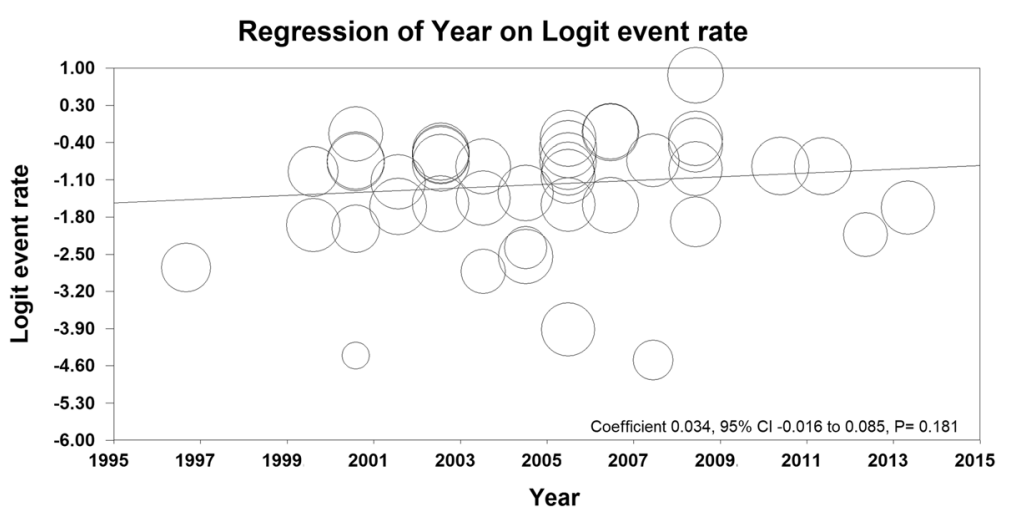

Fig. 6 Meta-regression of ROP prevalence based on years of studies

duration $(P<0.0001)$; however, preeclampsia significantly decreases the prevalence of ROP $(P=0.014)$.

\section{Discussion}

The present study is the first systematic and metaanalytic review on the prevalence and risk factors of ROP in Iran. The results of this meta-analysis showed that the prevalence of ROP in 18,000 Iranian premature infants was $23.5 \%$, and the prevalence for stages $1,2,3$, 4 and 5 was $7.9 \%, 9.7 \%, 2.8 \%, 2.9 \%$ and $3.6 \%$, respectively. In this study, the level of heterogeneity was high for ROP studies (95.6\%). The results of the subgroup analysis showed that geographic regions and the provinces could be a cause of high heterogeneity. However, this difference can be a reflection of studies conducted on different samples based on the GA or neonatal weight.
ROP is still a major cause of potentially preventable blindness around the world [23]. According to guidelines published by the American Academy of Ophthalmology, the American Academy of Children, and the American Association for Ophthalmology for Children and Strabismus for ROP screening, infants weighing less than $1500 \mathrm{~g}$ or $\mathrm{GA} \leq 30$ weeks, and infants weighing between 1500 and $2000 \mathrm{~g}$ or GA $>30$ weeks with an unstable clinical course should receive dilated ophthalmoscopy examinations for ROP [24].

The prevalence of ROP in various studies is mainly due to differences in mean GA and birth weight of infants in each study. Based on GA, the prevalence of ROP significantly decreases from $77.9 \%$ in GA $24-25$ to $1.1 \%$ in GA 30-31, which indicates the direct role of GA in ROP incidence. These results are completely consistent with the data published in other literature [25-31]. Moreover, in a meta-analysis study in Iran, the

Funnel Plot of Standard Error by Logit event rate

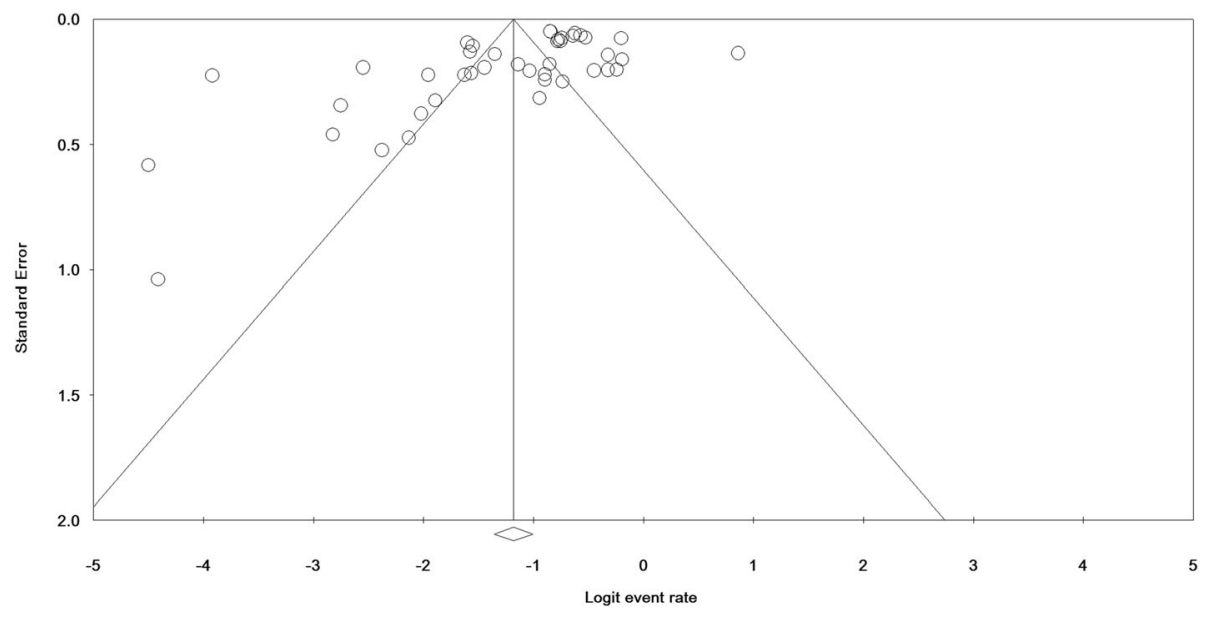

Fig. 7 Publication bias in the studies 
Table 3 Risk factor for retinopathy of prematurity in Iran

\begin{tabular}{|c|c|c|c|c|c|c|c|c|}
\hline \multirow[t]{2}{*}{ Variables } & \multirow[t]{2}{*}{ Studies $\left(N^{a}\right)$} & \multicolumn{2}{|c|}{ Sample $(N)$} & \multicolumn{2}{|c|}{ Heterogeneity } & \multirow[t]{2}{*}{ OR $\left(95 \% C C^{b}\right)$} & \multirow[t]{2}{*}{$P$-Value } & \multirow[t]{2}{*}{ Model in Meta-analysis } \\
\hline & & Case & Control & $1^{2}$ & $P$-Value & & & \\
\hline Twin birth & 4 & 804 & 1868 & 46.97 & 0.129 & 1.62 (0.94 to 2.81$)$ & 0.081 & Random $^{c}$ \\
\hline Mechanical ventilation & 6 & 1131 & 2493 & 73.35 & 0.002 & $1.81(0.80$ to 1.73$)$ & 0.39 & Random \\
\hline Continuous positive pressure ventilation & 2 & 62 & 131 & 64.11 & 0.095 & $3.97(1.21$ to 13.01$)$ & 0.023 & Random \\
\hline Blood transfusion $(\mathrm{N})$ & 16 & 1820 & 4167 & 91.34 & $<0.001$ & 2.38 (1.43 to 3.94$)$ & 0.001 & Random \\
\hline Septicemia & 11 & 1327 & 2965 & 80.75 & $<0.001$ & 1.96 (1.10 to 3.48$)$ & 0.021 & Random \\
\hline Birth weight < $1000 \mathrm{~g}$ & 9 & 573 & 2093 & 59.65 & 0.011 & 4.16 (2.35 to 7.35$)$ & $<0.001$ & Random \\
\hline Birth weight < $1500 \mathrm{~g}$ & 10 & 559 & 1984 & 43.34 & 0.069 & 3.74 (2.54 to 5.49$)$ & $<0.001$ & Random \\
\hline Phototherapy (N) & 11 & 1380 & 3355 & 80.69 & $<0.001$ & 1.50 (1.00 to 2.27$)$ & 0.049 & Random \\
\hline Oxygen therapy (N) & 14 & 726 & 3124 & 87.39 & $<0.001$ & 3.06 (1.29 to 7.27$)$ & 0.011 & Random \\
\hline Need for resuscitation & 2 & 56 & 212 & 86.50 & 0.006 & 5.01 (0.18 to 135.71$)$ & 0.338 & Random \\
\hline Apnea & 3 & 114 & 492 & 72.08 & 0.028 & 4.41 (1.70 to 11.40$)$ & 0.002 & Random \\
\hline Congenital heart disease & 2 & 50 & 246 & 67.29 & 0.08 & 2.13 (0.10 to 45.62) & 0.626 & Random \\
\hline Inter-ventricular hemorrhage & 11 & 1223 & 3178 & 76.36 & $<0.001$ & 2.24 (1.2 to 3.95$)$ & 0.005 & Random \\
\hline Acidosis & 3 & 132 & 296 & 62.62 & 0.069 & 2.56 (0.81 to 8.06$)$ & 0.106 & Random \\
\hline Cesarean section & 4 & 375 & 830 & 47.88 & 0.124 & 1.08 (0.53 to 2.18) & 0.82 & Random \\
\hline Preeclampsia & 2 & 108 & 237 & 0 & 0.82 & 0.12 (0.02 to 0.65$)$ & 0.014 & Fixed $^{d}$ \\
\hline Respiratory distress syndrome & 11 & 2039 & 2618 & 80.13 & $<0.001$ & 1.64 (1.03 to 2.61$)$ & 0.036 & Random \\
\hline Saturation above $50 \%$ & 4 & 118 & 656 & 30.30 & 0.23 & 8.35 (3.14 to 22.18) & $<0.001$ & Random \\
\hline Normal Vaginal Delivery & 4 & 375 & 830 & 46.63 & 0.132 & 1.01 (0.50 to 2.02) & 0.969 & Random \\
\hline Multiple pregnancy & 6 & 1199 & 2518 & 40.20 & 0.137 & 0.92 (0.73 to 1.16$)$ & 0.517 & Random \\
\hline Gestational age $\leq 28$ & 6 & 551 & 1440 & 75.88 & $<0.001$ & $5.20(2.31$ to 11.73$)$ & $<0.001$ & Random \\
\hline Gestational age $\leq 32$ & 9 & 689 & 1885 & 64.84 & 0.004 & 7.88 (4.62 to 13.46$)$ & $<0.001$ & Random \\
\hline Birth weight (gr) & 7 & 1495 & 2893 & 97.30 & $<0.001$ & 0.98 (0.97 to 0.99) & $<0.001$ & Random \\
\hline Gestational age (week) & 7 & 1495 & 2893 & 84.20 & $<0.001$ & 0.67 (0.59 to 0.770) & $<0.001$ & Random \\
\hline \multirow[t]{2}{*}{ Variables } & \multirow[t]{2}{*}{ Studies $\left(N^{a}\right)$} & \multicolumn{2}{|c|}{ Sample (N) } & \multicolumn{2}{|c|}{ Heterogeneity } & Mean Difference $\left(95 \% \mathrm{Cl}^{\mathrm{b}}\right)$ & $P$-Value & \\
\hline & & Case & Control & $1^{2}$ & $P$-Value & & & \\
\hline Gestational age (weeks) & 18 & 1835 & 4126 & 94.53 & $<0.001$ & $2.08(1.50$ to 2.66$)$ & $<0.001$ & Random \\
\hline Birth weight (gr) & 19 & 1782 & 4519 & 95.94 & $<0.001$ & $305.39(236.09$ to 374.69$)$ & $<0.001$ & Random \\
\hline Oxygen therapy (day) & 11 & 1399 & 3214 & 96.04 & $<0.001$ & $-4.36(-6.09$ to -2.63$)$ & $<0.001$ & Random \\
\hline Phototherapy (days) & 4 & 78 & 308 & 83.80 & $<0.001$ & $-2.08(-3.81$ to -0.35$)$ & $<0.001$ & Random \\
\hline Apgar score in the first minute & 3 & 174 & 216 & 63.30 & 0.66 & $1.07(0.45$ to 1.68$)$ & 0.001 & Random \\
\hline Apgar score & 3 & 64 & 272 & 76.34 & 0.015 & $0.43(-0.25$ to -1.13$)$ & 0.21 & Random \\
\hline Mechanical ventilation (days) & 2 & 114 & 154 & 88.81 & 0.003 & $-4.53(-9.17$ to 0.10$)$ & 0.55 & Random \\
\hline Bilirubin (mg/di) & 3 & 54 & 186 & 7.70 & 0.33 & $-0.27(-1.40$ to 0.86$)$ & 0.63 & Random \\
\hline Blood transfusion (duration) & 2 & 98 & 151 & 0 & 0.98 & $-0.69(-0.96$ to -0.42$)$ & $<0.001$ & Fixed \\
\hline clinical risk index for babies & 2 & 161 & 250 & 58.84 & 0.11 & $-0.62(-1.40$ to 0.16$)$ & 0.11 & Random \\
\hline
\end{tabular}

${ }^{\mathrm{a}}$ Number

${ }^{\mathrm{b}}$ Confidence interval

'Random effects model

${ }^{\mathrm{d}}$ Fixed effects model

prevalence of prematurity was reported to be $9.2 \%$ (95\% CI: 7.6-10.7) [32]. Therefore, the high prevalence of ROP in Iran (23.5\%) can be explained by the high prevalence of prematurity.
In a study by Tabarez-Carvajal et al. among 3018 premature infants, the incidence of stages $1,2,3,4$, and 5 was reported to be $8.34 \%, 8.78 \%, 1.9 \%, 0.03 \%$, and $0.30 \%$, respectively [33]. In another study by Abdel HA et al., 
Table 4 Risk factor for retinopathy of prematurity in other studies

\begin{tabular}{|c|c|c|c|}
\hline Study details & GA (weeks) & BW (gr) & Risk factors \\
\hline $\begin{array}{l}\text { Reyes et al., } 2017 . \\
\text { Oman [46] }\end{array}$ & $<32$ & $<1500$ & $\begin{array}{l}\text { low BW, low GA, duration of invasive ventilation, duration of oxygen therapy, duration of nasal } \\
\text { CPAP, late onset clinical or proven sepsis }\end{array}$ \\
\hline $\begin{array}{l}\text { Shah et al., } 2005 \\
\text { Singapore }[40]\end{array}$ & $<32$ & $<1500$ & Preeclampsia, low BW, prolonged duration of ventilation, pulmonary hemorrhage and CPAP \\
\hline $\begin{array}{l}\text { Yau et al., 2016, } \\
\text { China [45] }\end{array}$ & $\begin{array}{l}<32 \text { and } \\
>32\end{array}$ & $<1500$ & $\begin{array}{l}\text { low GA, low BW, preeclampsia, gestational diabetes mellitus, inotrope use, postnatal hypotension, } \\
\text { apgar score (1 min, } 5 \text { min and } 10 \text { min), respiratory distress syndrome, bronchopulmonary } \\
\text { dysplasia, invasive mechanical ventilation, surfactant use, oxygen supplement, patent ductus } \\
\text { arteriosus, thrombocytopenia, blood transfusion, anemia, NSAID use, sepsis }\end{array}$ \\
\hline $\begin{array}{l}\text { Abdel HA et al., 2012, } \\
\text { Egypt [34] }\end{array}$ & $\begin{array}{l}<32 \text { and } \\
>32\end{array}$ & $\begin{array}{l}<1500 \text { and } \\
>1500\end{array}$ & low GA, oxygen therapy, frequency of blood transfusions and sepsis \\
\hline $\begin{array}{l}\text { Chen et al., 2011, USA } \\
\text { [41] }\end{array}$ & $<30$ & $<1500$ & low GA, Sepsis, oxygen exposure \\
\hline $\begin{array}{l}\text { Hadi and Hamdy, } \\
\text { 2013, Egypt [37] }\end{array}$ & $<32$ & $<1250$ & low GA, low BW, Ventilation, blood transfusions, sepsis, Patent ductus arteriosus, IVH \\
\hline $\begin{array}{l}\text { Nair et al., 2001, } \\
\text { Oman [36] }\end{array}$ & $<32$ & $<1500$ & low BW, Low GA, TPN \\
\hline
\end{tabular}

BW Birth weight, GA Gestational age, PDA Patent ductus arteriosus, CPAP Continuous positive pressure ventilation, IVH Intraventricular hemorrhage, TPN Total parenteral nutrition

the prevalence of ROP stage 1 was $10.4 \%$, stage 2 was $5.2 \%$ and stage 3 was $3.45 \%$, and none of the infants had ROP at stages 4 or 5 [34]. But in the present study, the prevalence of ROP stages 4 and 5 was higher.

ROP is a multi-factorial disease, and in the present study, the strongest risk factor for ROP was prematurity and low birth weight. Most studies have demonstrated that prematurity and low birth weight are the strongest predictive factors of ROP, which indicates the crucial role of factors associated with the progression of the ROP disease [35-45].

After low birth weight and prematurity, exposure to oxygen for a long period and saturation over $50 \%$ were the most important risk factors for ROP in this study, which was consistent with the results of many other studies [42-47]. Due to inadequate antioxidant defense system, premature infants are not evolved to live in an oxygen-rich ectopic environment $[48,49]$. Oxidative stress is the result of various organs' exposure to free radicals of oxygen after being exposed to high concentrations of oxygen, which can lead to the progression of many pathogens such as ROP, necrotizing enterocolitis, IVH, bronchopulmonary dysplasia, and periventricular leukomalacia [50, 51].

In this study, other significant relationships with ROP were also found, including frequency and duration of blood transfusion, phototherapy, septicemia, apnea, IVH, and RDS. The comparison between the risk factors in our study and other reports is shown in Table 4.

\section{Conclusion}

Finally, it can be concluded that the present systematic review and meta-analysis summarizes the results of previous studies and provides a comprehensive view of ROP in Iran. Although the prevalence of ROP in Iran is similar to some developing countries, it is much higher than some other countries. Therefore, this fact highlights the importance of preventing and treating ROP and its following complications. To achieve a more favorable level and reduce the prevalence in the coming years, screening and close monitoring by experienced ophthalmologists are essential to diagnose and treat the common complications of prematurity and prevent visual impairment or blindness.

\section{Abbreviations \\ Cl: Confidence interval; GA: Gestational age; IVH: Intraventricular hemorrhage; PRISMA: Preferred Reporting Items for Systematic Reviews and Meta-Analyses Protocols; RDS: Respiratory Distress Syndrome; ROP: Retinopathy of prematurity; W: Week}

\section{Acknowledgements}

We thanks Behbahan University of Medical Sciences for the financial support.

Funding

Behbahan University of Medical Sciences.

Availability of data and materials

Because this article is a meta-analysis also the data extracted from the relevant articles in Iran.

\section{Authors' contributions}

MA was involved in study concept and design, acquisition of data, search, quality evaluation of studies, drafting of the manuscript, analysis and interpretation of data, critical revision of the manuscript for important intellectual content, approval of final version, and accountable for accuracy and integrity of the work. ZJ was involved in search, interpretation of data, acquisition of data, quality evaluation of studies, drafting of the manuscript, and approval of final version. ShR was involved in search, analysis and interpretation of data, quality evaluation of studies, drafting of the manuscript, and approval of final version. GhB was involved in study concept and design, acquisition of data, quality evaluation of studies, drafting of the manuscript, critical revision of the manuscript for important intellectual content, approval of final version, administrative, technical or material support and accountable for accuracy and integrity of the work. ADF was involved in search critical revision of the manuscript for important intellectual content, and approval of final version. 


\section{Ethics approval and consent to participate}

Not applicable.

\section{Consent for publication}

Not applicable.

\section{Competing interests}

The authors declare that they have no competing interests.

\section{Publisher's Note}

Springer Nature remains neutral with regard to jurisdictional claims in published maps and institutional affiliations.

\section{Author details}

${ }^{1}$ Student Research Committee, Ilam University of Medical Sciences, Ilam, Iran. ${ }^{2}$ Student Research Committee, Ilam University of Medical Sciences, Ilam, Iran. ${ }^{3}$ Iranian National ROP Committee, Tehran, Iran. ${ }^{4}$ Department of Pediatrics, Behbahan Faculty of Medical Sciences, Behbahan, Iran.

\section{Received: 18 September 2017 Accepted: 26 February 2018}

\section{Published online: 02 April 2018}

\section{References}

1. Zin A, Gole GA. Retinopathy of prematurity-incidence today. Clin Perinatol. 2013;40(2):185-200.

2. Gergely K, Gerinec A. Retinopathy of prematurity-epidemics, incidence, prevalence, blindness. Bratisl Lek Listy. 2009;111(9):514-7.

3. Zin A. R etinopathyof P re maturity-I ncidence to day. 2013.

4. Kliegman RM, Behrman RE, Jenson HB,et al. Nelson textbook of pediatrics Ebook: Elsevier health sciences; 2007.

5. Wilson CM, Ells AL, Fielder AR. The challenge of screening for retinopathy of prematurity. Clin Perinatol. 2013;40(2):241-59.

6. Gibson DL, Sheps SB, Schechter MT, et al. Retinopathy of prematurity: a new epidemic? Pediatrics. 1989;83:486-92.

7. Augsburger JJBN. Yanoff M, Duker JS, editors. Ophtalmology. St. Louis, MO: Mosby 2004. p. 1097-102.

8. Senthil MP, Salowi MA, Bujang MA, et al. Risk factors and prediction models for retinopathy of prematurity. Malays J Med Sci. 2015;22(5):57.

9. GEBEŞÇ A, USLU H, KELEŞ E, et al. Retinopathy of prematurity: incidence, risk factors, and evaluation of screening criteria. Turk J Med Sci. 2016;46(2): 315-20.

10. Edy Siswanto J, Sauer PJ. Retinopathy of prematurity in Indonesia: Incidence and risk factors. J Neonatal Perinatal Med. 2017;10(1):85-90. https://doi.org/ 10.3233/NPM-915142.

11. Naderian GIR, Mohammadizadeh M, Najafabadi FBZ, et al. The frequency of retinopathy of prematurity in premature infants referred to an ophthalmology Clinic in Isfahan. J Isfahan Med Sch. 29(128):126-30.

12. Gharebagh M, Sadeghi K, Zarghami N, Mostafidi H. Evaluation of vascular endothelial growth factor, leptin and insulin-like growth factor in precocious retinopathy. Urmia Med J. 2012;23(2):183-90.

13. Gharehbaghi MM, Peirovifar A, Sadeghi K. Plasma leptin concentrations in preterm infants with retinopathy of prematurity (ROP). Iran J Neonatol. 2012;3(1):12-6.

14. Nakhshab MAA, Dargahi S, Farhadi R, et al. The incidence rate of retinopathy of prematurity and related risk factors: a study on premature neonates hospitalized in two hospitals in sari, Iran, 2014-2015. J Kerman Univ Med Sci. 2016;23(3):296-307.

15. Badfar G, Shohani M, Nasirkandy MP, et al. Epidemiology of hepatitis B in pregnant Iranian women: a systematic review and meta-analysis. Arch Virol. 2018;163(2):319-330. https://doi.org/10.1007/s00705-017-3551-6.

16. Moher D, Liberati A, Tetzlaff J, Altman DG, PRISMA Group. Preferred reporting items for systematic reviews and meta-analyses: the PRISMA statement. PLoS Med. 2009;6(7):e1000097. https://doi.org/10.1371/ journal.pmed.1000097. Epub 2009 Jul 21

17. Sayehmiri K, Tavan H, Sayehmiri F, et al. Prevalence of epilepsy in Iran: a meta-analysis and systematic review. Iran J Child Neurol. 2014;8(4):9-17.

18. Wells GA, Shea B, O'Connell D, Peterson J, Welch V, Losos M, et al. The Newcastle-Ottawa Scale (NOS) for assessing the quality of nonrandomized studies in meta-analysis. 2011. Available: www.ohri.ca/programs/clinical epidemiology/oxford.asp. Accessed 25 Nov 2012

19. Higgins JP, Green S. Cochrane handbook for systematic reviews of interventions, vol. 4. Hoboken: Wiley; 2011.
20. Ades A, Lu G, Higgins J. The interpretation of random-effects meta-analysis in decision models. Med Decis Mak. 2005;25(6):646-54

21. Borenstein $M$, Hedges LV, Higgins J, et al. A basic introduction to fixedeffect and random-effects models for meta-analysis. Res Synth Methods. 2010;1(2):97-111.

22. Borenstein M, Hedges LV, Higgins J, Rothstein HR. Meta-Regression. Introduction to meta-analysis; 2009. p. 187-203.

23. Clemett R, Darlow B. Results of screening low-birth-weight infants for retinopathy of prematurity. Curr Opin Ophthalmol. 1999;10:155-63.

24. Ophthalmology AAoPSo. Screening examination of premature infants for retinopathy of prematurity. Pediatrics. 2013;131(1):189-95.

25. Isaza G, Arora S. Incidence and severity of retinopathy of prematurity in extremely premature infants. Can J Opthalmol. 2012;47:296-300.

26. Hwang $\mathrm{JH}$, Lee EH, Kim EA. Retinopathy of prematurity among very-lowbirth-weight infants in Korea: incidence, treatment, and risk factors. J Korean Med Sci. 2015;30(Suppl 1):S88S94.

27. Gunn DJ, Cartwright DW, Gole GA. Incidence of retinopathy of prematurity in extremely premature infants over an 18-year period. Clin Exp Ophthalmol. 2012:40:93-9.

28. Cerman E, Balci SY, Yenice OS, et al. Screening for retinopathy of prematurity in a tertiary ophthalmology Department in Turkey: incidence, outcomes, and risk factors. Ophthalmic Surg Lasers Imaging Retina. 2014;45: $550-5$.

29. Mitsiakos G, Papageorgiou A. Incidence and factors predisposing to retinopathy of prematurity in inborn infants less than 32 weeks of gestation. Hippokratia. 2016;20(2):121-6.

30. Bas AY, Koc E, Dilmen U; ROP Neonatal Study Group. Incidence and severity of retinopathy of prematurity in Turkey. Br J Ophthalmol. 2015:99(10):1311-4 https://doi.org/10.1136/bjophthalmol-2014-306286.

31. Group ETfRoPC. The incidence and course of retinopathy of prematurity: findings from the early treatment for retinopathy of prematurity study. Pediatrics 2005:116(1):15-23.

32. Vakilian K, Ranjbaran M, Khorsandi M, et al. Prevalence of preterm labor in Iran: a systematic review and meta-analysis. Int J Reprod Biomed. 2015;13(12):743-8

33. Tabarez-Carvajal AC, Montes-Cantillo M, Unkrich KH, et al. Retinopathy of prematurity: screening and treatment in Costa Rica. Br J Ophthalmol. 2017 101(12):1709-13. https://doi.org/10.1136/bjophthalmol-2016-310005. [Epub ahead of print]

34. Abdel HA, Mohamed GB, Othman MF. Retinopathy of prematurity: a study of incidence and risk factors in NICU of al-Minya University Hospital in Egypt. J Clin Neonatol. 2012;1(2):76-81. https://doi.org/10.4103/2249-4847.96755.

35. Bassiouny MR. Risk factors associated with retinopathy of prematurity: a study from Oman. J Trop Pediatr. 1996;42:355-8.

36. Nair PM, Ganesh A, Mitra S, et al. Retinopathy of prematurity in VLBW and extreme LBW babies. Indian J Pediatr. 2003;70:303-6.

37. Hadi AM, Hamdy IS. Correlation between risk factors during the neonatal period and appearance of retinopathy of prematurity in preterm infants in neonatal intensive care units in Alexandria, Egypt. Clin Ophthalmol. 2013;7:831-7.

38. Ratra D, Akhundova L, Das MK. Retinopathy of prematurity like retinopathy in full-term infants. Oman J Ophthalmol. 2017;10(3):167-172. https://doi.org/ 10.4103/ojo.OJO 1412016.

39. Sahin A, Sahin M, Türkcü FM, et al. Incidence of retinopathy of prematurity in extremely premature infants. ISRN Pediatr. 2014:2014:134347.

40. Shah VA, Yeo CL, Ling YL, et al. Incidence, risk factors of retinopathy of prematurity among very low birth weight infants in Singapore. Ann Acad Med Singap. 2005;34:169-78

41. Chen M, Citil A, McCabe F, et al. Infection, oxygen, and immaturity: interacting risk factors for retinopathy of prematurity. Neonatology. 2011;99:125-32

42. Darlow BA, Hutchinson JL, Henderson-Smart DJ, et al. Prenatal risk factors for severe retinopathy of prematurity among very preterm infants of the Australian and New Zealand neonatal network. Pediatrics. 2005;115:990-6.

43. Badriah C, Amir I, Elvioza SR, et al. Prevalence and 325 risk factors of retinopathy of prematurity. Paediatr Indones. 2012;52:138-44. 327

44. Rizalya D, Rudolf $T$, Rohsiswatmo R. Screening for 328 retinopathy of prematurity in hospital with limited facil- 329 ities. Sari Pediatri. 2012;14:185-90.

45. Yau GS, Lee JW, Tam VT, et al. Incidence and risk factors of retinopathy of prematurity from 2 neonatal intensive care units in a Hong Kong Chinese population. Asia Pac J Ophthalmol. 2016:5(3):18591. https://doi.org/10.1097/APO.0000000000000167. 
46. Reyes ZS, Al-Mulaabed SW, Bataclan F, et al. Retinopathy of prematurity: revisiting incidence and risk factors from Oman compared to other countries. Oman J Ophthalmol. 2017;10(1):26-32.

47. $\mathrm{Yu}$ VY, Upadhyay A. Neonatal management of the growth-restricted infant Semin Fetal Neonatal Med. 2004;9:403-9.

48. Weinberger $\mathrm{B}$, Laskin $\mathrm{DL}$, Heck DE, et al. Oxygen toxicity in premature infants. Toxicol Appl Pharmacol. 2002;181:60-7.

49. Hardy P, Beauchamp M, Sennlaub F, et al. New insights into the retinal circulation: inflammatory lipid mediators in ischemic retinopathy. Prostaglandins Leukot Essent Fatty Acids. 2005;72:301-25.

50. O'Donovan DJ, Fernandes CJ. Free radicals and diseases in premature infants. Antioxid Redox Signal. 2004;6:169-76.

51. Yoon HS. Neonatal innate immunity and toll-like receptor. Korean J Pediatr. 2010;53:985-8.

52. Naderian G, Parvaresh $M$, Rismanchiyan $A$, et al. Refractive errors after laser therapy for retinopathy of prematurity. Int J Ophthalmol. 2009;15(1):13-8.

53. Hosseini $H$, Farvardin M, Attarzadeh $A$, et al. Advanced retinopathy of prematurity at Poostchi ROP clinic, Shiraz. Bina J Ophthalmol 2009; 15(1):19-25.

54. Karkhaneh RER, Ghojehzadeh L, Kadivar M, et al. Incidence and risk factors of retinopathy of prematurity. Bina J Ophthalmol. 2005;11(1):81-90.

55. Nadeian GMH, Hadipour M, Sajjadi H. Prevalence and rsskfactor for retinopathy of prematuority in isfahan. Bina J Ophthalmol. 2010;15(3):208-13.

56. Mansouri MRKM, Karkhaneh R, Riazi Esfahani $M$, et al. Prevalence and risk factors of retinopathy of prematurity in very low birth weight or low gestational age infants. Bina J Ophthalmol. 2007;12(4):428-34.

57. Nakhshab MBG, Amiri A, Ashaghi M. Prevalence of preterm infant retinopathy in neonatal intensive care unit Buali Sari Hospital. J Mazandaran Univ Med Sci. 2003;13(39):63-70.

58. Daraie G, Nooripoor S, Ashrafi AM, et al. Incidence of retinopathy of prematurity and some related factors in premature infants born at amir-almomenin hospital in Semnan. Iran Koomesh. 2016;17(2):297-303.

59. Fayazi AHM, Fayzollazade M, GHolzar A, et al. Prevalence of retinopathy in preterm infants admitted to neonatal intensive care unit of Alzahra hospital in Tabriz. J Tabriz Univ Med Sci. 2009;30(4):63-6.

60. Sadeghi KHA, Hashemi F, Haydarzade M, et al. Prevalence and risk factors of retinopathy in preterm infants. J Tabriz Univ Med Sc. 2008:30(2):73-7.

61. Ebrahimiadib N, Roohipour R, Karkhaneh $\mathrm{R}$, et al. Internet-based versus conventional referral system for retinopathy of prematurity screening in Iran. Ophthalmic Epidemiol. 2016;23(5):292-7.

62. Ghaseminejad A, Niknafs P. Distribution of retinopathy of prematurity and its risk factors. Iran J Pediatr. 2011;21(2):209.

63. Khatami SF, Yousefi A, Bayat GF, et al. Retinopathy of prematurity among 1000-2000 gram birth weight newborn infants. Iran J Pediatr. 2008;18(2):137-42

64. Sabzehei MK, Afjeh SA, Farahani AD, et al. Retinopathy of prematurity: incidence, risk factors, and outcome. Arch Iran Med. 2013;16(9):507.

65. Saeidi R, Hashemzadeh A, Ahmadi S, et al. Prevalence and predisposing factors of retinopathy of prematurity in very low-birth-weight infants discharged from NICU. Iran J Pediatr. 2009;19(1):59-63.

66. Azinfar MAM, Pasha Z, Amad M. Prevalence of premature newborns discharged from NICU and infants in Shafizadeh Ami Children's hospital [dissertation]. Babol, Iran; Babol Univ Med; 2005.

67. Karkhanehyousefi NRA, Mekaniki A. Prevalence of retinopathy in immature newborns referred to eye Clinic of Shahid Beheshti Hospital in Babol [dissertation]. Babol, Iran; Babol Univ Med; 2009.

68. Ebrahimzade MKR, Esfahani M, Kadpour M, et al. The prevalence of retinopathy in preterm infants in preterm infants referred to Farabi hospital from the beginning of the year 2002 to the beginning of 2008 and the evaluation of short-term laser therapy results [dissertation]. Tehran: Islamic Azad Univ Med; 2009.

69. Mirzaee SA, Mohagheghi P. Determine the prevalence of retinopathy (ROP) in infants admitted to the NICU department of Milad Hospital [dissertation]. Tehran: Islamic Azad Univ Med; 2010.

70. Mousavi SZ, Karkhaneh R, Riazi-Esfahani M, et al. Retinopathy of prematurity in infants with late retinal examination. J Ophthalmic Vis Res. 2009;4(1):24.

71. Foladinezhad MMM, GHarib M, SHishari F, Soltani M. Frequency, severity and some risk factors of retinopathy in premature infants of Taleghani Hospital in Gorgan. J Gorgan Univ Med Sc. 2009;11(2):51-4.

72. Mousavi SZKR, Riazi-Esfahani M, Mansouri MR, et al. Incidence, severity and risk factors for retinopathy ofPrematurity in premature infants with late retinal examination. Bina J Ophthalmol. 2008;13(4):412-7.
73. Sadeghzadeh M, Khoshnevisasl P, Parvaneh M, et al. Early and late outcome of premature newborns with history of neonatal intensive care units admission at 6 years old in Zanjan. Northwestern Iran Iran J Child Neurol. 2016;10(2):67.

74. Bayat-Mokhtari M, Pishva N, Attarzadeh A, et al. Incidence and risk factors of retinopathy of prematurity among preterm infants in shiraz/Iran. Iran J Pediatr. 2010;20(3):303.

75. Karkhaneh R, Shokravi N. Assessment of retinopathy of prematurity among 150 premature neonates in Farabi eye hospital. Acta Med Iran. 2001;39(1):35-8.

76. Babaei H, Ansari MR, Alipour AA, et al. Incidence and risk factors for retinopathy of prematurity in very low birth weight infants in Kermanshah. Iran World Appl Sci J. 2012;18(5):600-4.

77. Abrishami M, Maemori G-A, Boskabadi $\mathrm{H}$, et al. Incidence and risk factors of retinopathy of prematurity in Mashhad. Northeast Iran Red Crescent Med J. 2013;15(3):229.

78. Riazi-Esfahani M, Alizadeh Y, Karkhaneh R, et al. Retinopathy of prematurity: single versus multiple-birth pregnancies. J Ophthalmic Vis Res. 2008;3(1):47.

79. Alizadeh Y, Zarkesh M, Moghadam RS, et al. Incidence and risk factors for retinopathy of prematurity in north of Iran. J Ophthalmic Vis Res. 2015;10(4):424.

80. Mousavi SZ, Karkhaneh R, Roohipoor R, et al. Screening for retinopathy of prematurity: the role of educating the parents. J Ophthalmol. 2010;22(2):13-8.

81. MousavibS Zb EM, Roohipoor $\mathrm{R}$, Jabbarvand $\mathrm{M}$, et al. Characteristics of advanced stages of retinopathy of prematurity. J Ophthalmol. 2010;22(2):19-24.

82. Feghhi M, Altayeb $\mathrm{SMH}$, Haghi $\mathrm{F}$, et al. Incidence of retinopathy of prematurity and risk factors in the south-western region of Iran. Middle East Afr J Ophthalmol. 2012;19(1):101.

83. Afarid $M$, Hosseini $H$, Abtahi B. Screening for retinopathy of prematurity in south of Iran. Middle East Afr J Ophthalmol. 2012;19(3):277.

84. Ahmadpour-kacho M, Zahed Pasha Y, Rasoulinejad SA, et al. Correlation between retinopathy of prematurity and clinical risk index for babies score. J Tehran Univ Med S. 2014;72(6):404-11.

85. Ahmadpour-Kacho M, Jashni Motlagh A, Rasoulinejad SA, et al. Correlation between hyperglycemia and retinopathy of prematurity. Pediatr Int. 2014; 56(5):726-30.

86. Rasoulinejad SA, Montazeri M. Retinopathy of prematurity in neonates and its risk factors: a seven year study in northern iran. Open Ophthalmol J. 2016;10:17.

87. Karkhaneh R, Mousavi S-Z, Riazi-Esfahani M, et al. Incidence and risk factors of retinopathy of prematurity in a tertiary eye hospital in Tehran. $\mathrm{Br} J$ Ophthalmol. 2008;92(11):1446-9.

88. Khalesi N, Shariat M, Fallahi M, et al. Evaluation of risk factors for retinopathy in preterm infant: a case-control study in a referral hospital in Iran. Minerva Pediatr. 2015;67(3):231-7

89. Ebrahim M, Ahmad RS, Mohammad M. Incidence and risk factors of retinopathy of prematurity in Babol. North of Iran Ophthalmic Epidemiol. 2010;17(3):166-70

90. Roohipoor R, Karkhaneh R, Farahani A, et al. Retinopathy of prematurity screening criteria in Iran: new screening guidelines. Arch Dis Child Fetal Neonatal Ed. 2016;101(4):F288-F93.

91. Mansouri M, Hemmatpour S, Sedighiani F, et al. Factors associated with retinopathy of prematurity in hospitalized preterm infants in Sanandaj. Iran Electronic physician. 2016:8(9):2931

\section{Submit your next manuscript to BioMed Central and we will help you at every step:}

- We accept pre-submission inquiries

- Our selector tool helps you to find the most relevant journal

- We provide round the clock customer support

- Convenient online submission

- Thorough peer review

- Inclusion in PubMed and all major indexing services

- Maximum visibility for your research

Submit your manuscript at www.biomedcentral.com/submit 